\title{
Compliance of Diabetic Patients: Pros and Cons
}

\author{
Eman Taher *, Gehan Hamdy**, Soad Sultan**, Hebat'Allah Moustafa**
}

\begin{abstract}
Diabetes is a major public health problem allover the world. This study was conducted to demonstrate the pattern of compliance among diabetic patients as regard appointment, diet and drugs, its determinants and reasons beyond noncompliance. This cross-sectional study was conducted at the outpatient Clinic of Diabetes, Kasr AIAini. The compliance pattern was assessed using special scoring system. The different determinants of the compliance as regard socio demographic, disease characteristics, and care characteristics were also assessed. The quality of care was measured based on the weighted care score. Fasting blood sugar, was done to all patients. Patients were interrogated for reasons beyond non compliance through open ended questions. Improper compliance to diet was prevalent ([34.7\%]) of study sample the significant determinants of improper compliance to diet were younger age, type 1 diabetes, long duration of illness, absence of complication, positive family history, receiving 3 or more drugs per day, and improper compliance to drugs. Financial constraints and psychological constraints were beyond improper diet and drugs compliance. The study included that compliance to appointment and drugs was better than compliance to diet. Cost and psychological constraints were among the main reasons of improper compliance.
\end{abstract}

Keywords: Compliance, Diabetes, Determinant

\section{INTRODUCTION}

Diabetes is a major public health problem allover the world. The World Health Organization (WHO) estimates that more than 180 million people worldwide have diabetes. This number is likely to be more than double by $2030^{[1]}$. The clinical and economic burden from the disease arise from the fact that; people with diabetes have a two-to-four fold increased risk of cardiovascular disease compared to the general population and increased incidence of retinopathy, peripheral nerve

\footnotetext{
*Public Health Department, Kasr AIAini Cairo University

**Internal Medicine Department. Kasr AIAini Cairo University
} 
damage and renal problems ${ }^{[2]}$.

In spite of complexity of care regimen, patients with good diabetes self-care behaviors can attain excellent glycemic control. However, many patients do not achieve good glycemic control and continue to suffer health problems as a result ${ }^{[3]}$.

A dictionary definition of "compliance" suggests a disposition to yield to or comply with the wishes of others. Compliance in a medical context refers to a patient both agreeing to and then undergoing some part of their treatment program as advised by their doctor or other healthcare worker [4,5]. Much of the medical community especially primary care providers in active clinical practice has adopted this concept, and the term "noncompliance" remains the standard description of adverse patient behavior toward their treatment program [6,7].

The first step to improve patient compliance is to understand why noncompliance occurs. A number of factors related to diabetes regimen compliance problems as demographic, psychological, and social factors, as well as health care provider, medical system, and disease- and treatment-related factors have been well documented ${ }^{[8]}$.

Patients selected for this study were diabetes because they are chronic patients required to follow a complex regimen and computably they face a compliance problem. This study was conducted to demonstrate the pattern of compliance among diabetic patients, its determinants (what is with and what is against) and reasons beyond noncompliance from the patient point of view.

\section{MATERIAL AND METHODS:}

\section{Study setting and design:}

This cross section study was conducted at the outpatient Clinic of Diabetes, Cairo University, over a period of 4 months from June to September, 2008.

\section{Study participants:}


The study enrolled a total of 300 patients who were regularly registered and followed-up at the clinic for at least one year prior to their inclusion in the study.

\section{Ethical Considerations:}

Data confidentiality was preserved in accordance with the Revised Helsinki Declaration of Bioethics ${ }^{[9]}$. All patients were informed about the aim of the study and written informed consents were obtained from the participants.

\section{METHODS:}

All the patients were interrogated by a pretested questionnaire covering the following items:

1. Sociodemographic characteristics

2. Disease characteristics.

3. Compliance pattern:

- Compliance to appointment: it was assessed by calculating the ratio of attendance to the number of predetermined and set appointments. A score of 3 was given to patients attending the clinic $5 / 6$ or $6 / 6$ times in the last 6months (proper compliance), a score of 2 was given to patients attending the clinic $3 / 6$ or $4 / 6$ times (fair compliance), and a score of 1 was given to patients attending the clinic less than 3/6 times (poor compliance).

- Compliance to diet regimen: According to what was stated by the patients; a score of 3 was given to patients who said that they are strictly compliant to the regimen in the last month (proper compliance), a score of 2 was given to patients who are sometimes compliant (fair compliance), and a score of 1 was given to patients who are not compliant at all (poor compliance).

- Compliance to drug regimen: According to what was stated by the patients; a score of 3 was given to patients who said that they are strictly compliant to the regimen in the last month (proper compliance), a score of 2 was given to patients who ignored treatment 1 to 3 times per month (fair compliance), and 
a score of 1 was given to patients who ignored treatment more than 3 times per month (poor compliance).

Scoring of compliance was done according to Khattab etal[10].

- Non compliant patients were asked about reasons of improper compliance through open ended questions.

4-Measurement of quality of care:

We based our measures on the

Diabetes Quality Improvement Project (DQIP). Detailed descriptions of each measure are publicly available through the Internet ${ }^{[11]}$. The measures derived from DQIP were as follows: medical record documentation of blood pressure measurement every time the patient attend the clinic, fasting blood sugar, an eye examination, foot examination, laboratory examination for $\mathrm{HbA}_{1 \mathrm{c}}$, lipid panel, and urine microalbumin screen in the previous year. A scoring system was calculated to assess the quality of care.

We use the weighted care score proposed by Gulliford et al[12]. This score takes into account the importance of glycemic and blood pressure measurements relatively to other measurements, so a score was calculated in which glucose and blood pressure measurement were given a weighted score of 4 ; while the other measurements were given a score of 1 (total score of 13)

5-Assesment of glycaemic control:

We depend upon the fasting blood glucose (FBS) rather than $\mathrm{HbA}_{1 c}$ as it is cheaper and can be done at the outpatient clinic. Good glycemic control is defined when FBS is $<130 \mathrm{mg} / \mathrm{dl}$ and poor control was defined when FBS is $\geq 130^{[13]}$

\section{Statistical analysis}

Data were collected and analyzed using the statistical package for social sciences (SPSS) version $11 . \quad$ Univariate relationships between the dependent variables (degree of compliance with diet, drugs and appointment) and independent variables related to patients, disease and 
care characteristics were examined using the chi-square test for categorical variables and student t-test for continuous variables. A $p$ value of 0.05 was used as the cut-off level for statistical significance. Multivariate analysis (logistic regression) was performed with non-compliance as the dichotomous outcome variable with those variables which were significant in the chisquare as predictor variables in order to calculate adjusted odds ratios (OR) and 95\% confidence intervals $(\mathrm{Cl})$.

\section{RESULTS:}

General characteristics of the patients (table 1):

Three hundred patients were recruited in this study with age ranged from 16-66 years. Nearly three fourths of the patients were females. Most of the patients were married coming from urban areas, and nearly half of them were illiterate. $92.7 \%$ of them were suffering from type 2 diabetes with duration ranged from one to 26 years. About one third of them were suffering from different types of complications especially macrovascular complication in the form of cardiovascular and cerebrovascular diseases. More than half of the patients showed positive family history of diabetes. All of the patients received treatment for diabetes and $60 \%$ of them received treatment for other diseases as liver cirrhosis (33\%), hypertension (31\%) and coronary heart disease (20\%).

\section{Compliance of diabetic patients (table 2} - 5):

Improper compliance to diet was more prevalent than improper compliance to drugs and appointment (104 [34.7 \%]vs. 67[22.3 \%] vs. 53[17.7 \%]respectively). [Table 2]

As regard to patient characteristics: literate, working married patients were significantly less compliant to appointment, while young aged patients were significantly less compliant to diet. Urban residence was the only significant determinant to improper compliance to drugs. [Table 3] 
Regarding disease characteristics; patient with controlled blood glucose levels type 1 diabetes and long duration of the attending the clinic less regularly than disease were significant determinants to those with uncontrolled levels. Patients improper diet compliance. Presence of with improper compliance to the diet and complication was significantly associated with improper compliance to appointment, on the other hand absence of complication was significantly associated with improper diet and drug compliance. Previous experience of the disease among the relatives of patients had a significant negative impact on patient's compliance to appointment and diet. [Table 4]

Regarding care characteristics; receiving three or more drugs per day was significantly associated with improper appointment, diet and drug compliance, while single daily dose administration of drugs was significantly associated with improper compliance to appointment only. [Table 5]

Quality of care showed no significant relation to pattern of compliance among the patients.As regard to glycaemic control, drug regimens showed high level of blood glucose [Table 5]

Logistic regression analysis was done and it included only the significant determinants that result from the univariate analysis that affect appointment, diet, drugs and total compliance in order to demonstrate the significant predictors of compliance. The analysis reveled that: [Table 6]

Significant predictors of improper appointment compliance were mainly related to numbers and frequency of drugs taken by the patients. Significant predictors to improper diet compliance were younger age, increase duration of the disease, +ve family history, and improper drug compliance. The only significant predictor to improper drug compliance was improper diet compliance, while + ve family history 
was the only significant predictors to be a good significant predictor to improper total compliance. compliance with diet (odd's ratio $=24.2$ ),

As regard to main reasons of and on the other hand compliance to diet improper compliance as stated by the was a significant predictor to compliance to patients: felt good health was the main reason beyond improper appointment (32.1\%), while financial constraints were beyond improper diet and drugs drugs (odds' ratio $=11.1$ ). This fact is supported by the study conducted by Khattab et al[10] who mentioned also that compliance $\quad(41.3 \%$ and $\quad 70.1 \%$ respectively). [Table 7]

\section{DISCUSSION:}

In general, research has shown that the diabetes regimen is multidimensional, and compliance to one regimen component may be unrelated to compliance in other regimen areas ${ }^{[14,15]}$. It has been generally acknowledged for years that noncompliance rates for chronic illness regimens and for lifestyle changes are $\propto$ $50 \%[14]$. Our results are in agreement with this finding (49.3\%).

This study shows better compliance to appointment and drugs rather than to diet. Also compliance with drugs was found to compliance with some aspect of diabetic regimen as appointment and drugs can predict compliance with other aspect as diet (odds' ratio3.1 and 14.9 respectively).

Appointment compliance in this study is higher than that reported by Diabetes Attitudes, Wishes and Needs (DAWN) study recently interviewed over 5000 persons with diabetes in 13 countries around the world ${ }^{[16]}$. This higher figure is due to the fact that some of the drugs are dispensed free of charge every month to the diabetic patients in the outpatient clinic in Kasr El-Aini hospital. So the patients are keen to attend the clinic on regular basis every month. This finding is also supported by a higher rate of drug compliance than 
reported by other study ${ }^{[17]}$.

The pattern of diet compliance in this study is in concordance with that reported by Kravitz etal[15] $(65.3 \%$ vs. $65 \%$ respectively) but it is higher than the results of DAWN studyl ${ }^{[16]} \quad(65.3 \%$ vs. $37 \%$ respectively). Low level of diet compliance reported by DAWN study may be due to variability of the dietary habits in different nations all over the world.

As regard to sociodemographic determinants, younger age was associated significantly with bad diet compliance, but with good appointment compliance. Literate working patients showed significant bad appointment compliance and this may be related to unsuitable clinic time as in Kasr El-Aini hospital all the clinic are working from 8am to 2 am only. This time coincides with time of work for the working patients. Another explanation may be related to high socioeconomic level of the literate working patients that allow them to follow up their health status in the health insurance system or on private basis. The literate working patients also showed bad diet and drug compliance that may be secondary to bad appointment compliance This result is in contradictory to Delamater etal[8] who stated that demographic factors such as ethnic minority, low socioeconomic status, and low levels of education have been associated with lower regimen adherence and greater diabetes-related morbidity.

As regard to disease determinants, patients with type 2 diabetes showed less compliance to appointment and drugs than patients with type 1 and this relates to the nature of type 1 diabetes which occur at young age. Research in this area has associated various psychological factors beyond this finding. These factors include encouragement and support from parents, fear of complications, will power, motivation, and a sense of normality. On the other hand patients with type 1 diabetes demonstrated significantly less 
diet compliance than patients with type 2 diabetes as this group of patients wish to have a similar lifestyle to their peers, and the other physical, emotional and social changes, can all affect the ability to manage their lifestyle properly[18]. Better adherence for type 1 than for type 2 diabetic patients across most regimen domains was also observed by DOWN study[16].

Research has generally shown that lower regimen adherence can be expected when a health condition is chronic ${ }^{[21]}$. Longer duration of diabetes was associated with bad compliance to appointment, and diet. Logistic regression analysis supported this finding especially for diet compliance. Similar result was obtained by Khattab et al[10] who mentioned that increasing duration of diabetes was found to be the predictive of decreasing total compliance score.

In the current study, despite the presence of complication was associated with bad appointment, it was associated with good diet and drug compliance and this may be explained by: presence of complication may limits the movement of the patients but its burden enforce the patients to follow the diet and drug regimen to decrease its severity. This finding is in agreement with that reported by Dietrich [19] who concluded that when diabetes complications started, the patients' compliance improved. Among diabetesrelated factors significantly associated with low ratings of compliance was positive family history of diabetes as stated by Clarke and Goosen[20]. Similar results was drown from this study and this could be explained by; presence of diabetic relative may give the patient the sense of being more familiar with the disease and this consequently may reflect on their compliance.

As regard to care determinants, research among diabetic patients indicates that simple regimen where patients take 
only one type of drug, once a day, yields better compliance. Decreases in compliance of $22 \%$ for each increase in frequency of daily dosing had been found [21]. Our results support this finding as $100 \%$ of patients receiving single daily dose are good compliant to medication than those receiving 2 or 3 doses per day.

Studies of compliance with oral hypoglycemic drugs (OHDs) and insulin prescriptions showed compliance rates averaging approximately $75 \%$ for OHDs compliance and $63 \%$ for insulin compliance [21].Our data also demonstrated higher rate of compliance to OHDs than to insulin.

Polypharmacy is the natura consequence of providing evidence-based medical care to patients with type 2 diabetes ${ }^{[22]}$. Patient compliance to prescribed medications is crucial to the goal of reaching metabolic control. Improper compliance in this study was associated with receiving 3 or more drugs per day. Logistic regression analysis demonstrated that the significant predictors to improper appointment was taking 3 or more medication per day in repeated 3 or more doses

Good care was found to be associated with better compliance. This might be explained by the increasing satisfaction of the diabetic patients with the improving quality of care and their relationship with the outpatient clinic team, which are important determinants of good compliance [23]. Similar finding is obtained by Khattab et al ${ }^{[10]}$. Although no significant difference was detected as regard to care score, yet lower scores were associated with improper compliance.

A wide variety of studies demonstrated that patients who fail to adhere to prescribed clinical regimens have very poor glycaemic control [24]. Similar result from our study is in concordance with these finding.

To improve patient compliance, it is important to understand why 
noncompliance occurs ${ }^{[8]}$. In this study, patient health (whether good or bad) accounts for $52.9 \%$ of causes of non compliance with appointment. Cost is one of the issues that affect patient compliance [25]. In this study cost is responsible for $70.1 \%$ of causes of noncompliance to drugs and $41.3 \%$ of non compliance to diet. Although some of the drugs were dispensed free at the out patient clinic, it is still not sufficient to all patients all the time.

Depression is at least twice as common in patients with diabetes as compared with the non-diabetic population and it affects as many as one-quarter of patients with diabetes. It may contribute to problematic medication use, due to increase in forgetfulness and/or a loss of interest in protecting one's health [26]. This study shows that psychological constraints accounted for more than quarter of causes of non compliance to diet as well as nearly one fifth of causes of bad drug compliance in the form of forgetfulness and not feeling any benefits of treatment.

\section{Limitation to the study:}

We purposely chose patients with diabetes because we wanted to study people with a chronic illness who faced a challenging compliance regimen, but this leaves unresolved question about whether our findings would generalize to other patient populations in different settings. Our study highlights some determinants of compliance with some aspects of the diabetic regimen in Egypt. Further studies are needed to explore the impact of social factors, such as family cohesion and support, psychological factors and quality of life.

\section{CONCLUSION:}

Compliance to appointment and drugs are better than compliance to diet. Improper compliance in general is determined by: older age, literacy, working, type 2 diabetes, long duration of the disease, absence of complication, positive family history, and polypharmacy. Cost and 
psychological depression are among the main reasons of improper compliance.

\section{Recommendations:}

1. The first step to improve compliance is to have some protocol of assessment of noncompliance.

2. Empowerment of the role of (Non Governmental Organizations) in providing the required drugs to patients free of charge or at low cost.

3. Appointment of a behavioral health specialist to help in breaking the cycle of depression and poor compliance through cognitivebehavioural therapy.

4. Appointment of nutritionist at the diabetes clinic to enforce the dietary educational programs.

5. Organize the clinic time to become more suitable to working patients.

\section{Acknowledgements}

The authors would like to thank the paramedical staff of the diabetic clinic in Kasr El Aini hospital. As well as all the diabetic patients who agreed to participate in this work. 
Table (1): General characteristics of the participants

\begin{tabular}{|c|c|}
\hline Patients characteristics & Value \\
\hline \#Age & $49.2 \pm 9.6$ \\
\hline $\begin{array}{r}\text { Sex [No (\%)]: Male } \\
\text { Female }\end{array}$ & $\begin{array}{l}71(23.7) \\
229(76.3)\end{array}$ \\
\hline $\begin{array}{r}\text { Residence [No (\%)]: Urban } \\
\text { Rural }\end{array}$ & $\begin{array}{l}271(90.3) \\
29(9.7)\end{array}$ \\
\hline $\begin{aligned} & \text { Marital status [No (\%)]: } \text { Married } \\
& \text { Single } \\
& \text { Divorced or Widow }\end{aligned}$ & $\begin{array}{c}240(80.0) \\
13(4.3) \\
47(15.7) \\
\end{array}$ \\
\hline $\begin{array}{l}\text { Education level [No (\%)] } \\
\text { Illiterate/read and write } \\
\text { Primary } \\
\text { Secondary and higher } \\
\end{array}$ & $\begin{array}{l}178(59.3) \\
46(15.3) \\
76(25.0)\end{array}$ \\
\hline $\begin{array}{l}\text { Occupation [No (\%)] } \\
\text { House wife } \\
\text { Non skilled laborer } \\
\text { Skilled laborer } \\
\text { Employee } \\
\text { Not working men } \\
\end{array}$ & $\begin{array}{c}213(71.0) \\
39(13.0) \\
6(2.0) \\
37(12.3) \\
5(1.7) \\
\end{array}$ \\
\hline $\begin{array}{r}\text { Smoking [No (\%)]: Smoker } \\
\text { Not smoker }\end{array}$ & $\begin{array}{c}27(9.0) \\
273(91.0)\end{array}$ \\
\hline \multicolumn{2}{|c|}{ Disease characteristics } \\
\hline $\begin{array}{r}\text { Type of Diabetes [No (\%)]: Type } 1 \\
\text { Type } 2\end{array}$ & $\begin{array}{c}22(7.3) \\
278(92.7)\end{array}$ \\
\hline \#Duration of diabetes & $8.1 \pm 5.4$ \\
\hline $\begin{array}{l}\text { Complication [No (\%)] } \\
\text { No } \\
\text { Macro vascular complication } \\
\text { Micro vascular complication } \\
\text { Diabetic coma }\end{array}$ & $\begin{array}{c}201(67.0) \\
86(28.7) \\
8(2.7) \\
5(1.6) \\
\end{array}$ \\
\hline $\begin{array}{r}\text { Family history [No (\%)]: Positive } \\
\text { Negative }\end{array}$ & $\begin{array}{l}165(55.0) \\
135(45.0)\end{array}$ \\
\hline \#FBS & $173.4 \pm 57.6$ \\
\hline \#Post prandial blood sugar & $250 \pm 77.3$ \\
\hline$\# \mathrm{HbA}_{1 \mathrm{c}}(\mathrm{N}=31)$ & $8.6 \pm 1.5$ \\
\hline \multicolumn{2}{|c|}{ Care characteristics } \\
\hline $\begin{array}{l}\text { Type of treatment [No (\%)] } \\
\text { Oral hypoglycemic } \\
\text { Insulin injection } \\
\text { Both }\end{array}$ & $\begin{array}{l}140(46.7) \\
72(24.0) \\
88(29.3)\end{array}$ \\
\hline $\begin{array}{c}\text { Frequency/day [No (\%)]: Once } \\
\text { Twice } \\
\text { Three or more }\end{array}$ & $\begin{array}{c}9(3.0) \\
242(80.7) \\
49(16.3)\end{array}$ \\
\hline \#Care score & $6.3 \pm 3.3$ \\
\hline
\end{tabular}


Table (2): Pattern of compliance of diabetic patients

\begin{tabular}{|l|c|c|}
\hline Pattern of compliance & No & Percent \\
\hline Appointment compliance & & \\
Proper & 247 & 82.3 \\
Fair & 38 & 12.7 \\
Poor & 15 & 5.0 \\
\hline Diet compliance & 196 & \\
Proper & 96 & 65.3 \\
Fair & 8 & 32.0 \\
Poor & & 2.7 \\
\hline Drug compliance & 233 & \\
Proper & 61 & 77.7 \\
Fair & 6 & 20.3 \\
Poor & & 2.0 \\
\hline Total compliance & 152 & \\
Proper & 138 & 50.7 \\
Fair & 10 & 46.0 \\
Poor & & 3.3 \\
\hline
\end{tabular}

Table (3): Effect of patient characteristics on appointment, diet and drugs compliance.

\begin{tabular}{|c|c|c|c|c|c|c|c|c|c|}
\hline Variables & \multicolumn{3}{|c|}{ Appointment } & \multicolumn{3}{|c|}{ Diet } & \multicolumn{3}{|c|}{ Drugs } \\
\hline & 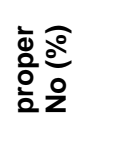 & $\begin{array}{l}\text { ळे응 } \\
\text { 흘을 }\end{array}$ & 0 & 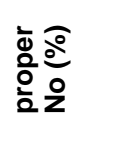 & $\begin{array}{l}\text { ळे응 } \\
\text { 흘을 }\end{array}$ & 0 & 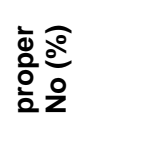 & $\begin{array}{l}\text { 훙ㅎㅁ } \\
\text { 흘을 }\end{array}$ & $\mathbf{P}$ \\
\hline $\begin{array}{l}\text { Total } \\
\text { number }\end{array}$ & 247 & 53 & & 196 & 104 & & 233 & 67 & \\
\hline $\begin{array}{l}\text { Age } \\
\text { Mean } \\
\pm \mathrm{SD}\end{array}$ & $\begin{array}{l}48.9 \\
\pm 9.6\end{array}$ & $\begin{array}{l}50.7 \\
\pm 9.6\end{array}$ & 0.21 & $\begin{array}{l}50.6 \\
\pm 7.3\end{array}$ & $\begin{array}{r}46.6 \\
\pm 12.5\end{array}$ & .001 & $\begin{array}{l}49.2 \\
\pm 9.6\end{array}$ & $\begin{array}{l}49.2 \\
\pm 9.6\end{array}$ & .09 \\
\hline $\begin{array}{l}\text { Sex } \\
\text { Male } \\
\text { Female }\end{array}$ & $\begin{array}{c}62(87.3) \\
185(80.8)\end{array}$ & $\begin{array}{c}9(12.7) \\
44(19.2)\end{array}$ & 0.13 & $\begin{array}{l}47(66.2) \\
149(65.1\end{array}$ & $\begin{array}{l}71(33.8) \\
80(34.9)\end{array}$ & .49 & $\begin{array}{c}51(71.8) \\
182(79.5)\end{array}$ & $\begin{array}{l}20(28.2) \\
47(20.5)\end{array}$ & .11 \\
\hline $\begin{array}{l}\text { Residence } \\
\text { Urban } \\
\text { Rural }\end{array}$ & $\begin{array}{c}226(83.4) \\
21(72.4)\end{array}$ & $\begin{array}{c}45(16.6) \\
8(27.6)\end{array}$ & 0.11 & $\begin{array}{l}173(63.8 \\
23(79.3) \\
\end{array}$ & $\begin{array}{c}98(36.2) \\
6(20.7)\end{array}$ & .06 & $\begin{array}{c}206(76.0) \\
27(93.1)\end{array}$ & $\begin{array}{c}65(24.0) \\
2(6.9)\end{array}$ & .02 \\
\hline $\begin{array}{l}\text { Marital } \\
\text { status } \\
\text { Married } \\
\text { Unmarried }\end{array}$ & $\begin{array}{c}195(81.3) \\
52(86.7)\end{array}$ & $\begin{array}{c}45(18.7) \\
8(13.3)\end{array}$ & 0.21 & $\begin{array}{l}155(64.6 \\
41(68.3)\end{array}$ & $\begin{array}{l}85(35.4) \\
19(31.7)\end{array}$ & .35 & $\begin{array}{c}183(76.3) \\
50(83.3)\end{array}$ & $\begin{array}{l}57(23.8) \\
10(16.7)\end{array}$ & .17 \\
\hline $\begin{array}{l}\text { Education } \\
\text { Illiterate } \\
\text { Literate }\end{array}$ & $\begin{array}{c}155(87.1) \\
92(75.4)\end{array}$ & $\begin{array}{l}23(12.9) \\
30(24.6)\end{array}$ & $\stackrel{*}{*}$ & $\begin{array}{l}123(69.1 \\
73(59.8)\end{array}$ & $\begin{array}{l}55(30.9) \\
49(40.2)\end{array}$ & .06 & $\begin{array}{c}139(78.1) \\
94(77.0)\end{array}$ & $\begin{array}{l}39(21.9) \\
28(23.0)\end{array}$ & .47 \\
\hline $\begin{array}{l}\text { Occupation } \\
\text { Not working } \\
\text { Working }\end{array}$ & $\begin{array}{c}187(85.8) \\
60(73.2)\end{array}$ & $\begin{array}{l}31(14.2) \\
22(26.8)\end{array}$ & $\stackrel{*}{*}$ & $\begin{array}{l}142(65.1 \\
54(65.9) \\
\end{array}$ & $\begin{array}{l}76(34.9) \\
28(34.1) \\
\end{array}$ & .51 & $\begin{array}{c}169(77.5) \\
64(78.0) \\
\end{array}$ & $\begin{array}{l}49(22.5) \\
18(22.0)\end{array}$ & .52 \\
\hline $\begin{array}{l}\text { Smoking } \\
\text { Smoker } \\
\text { Not smoker }\end{array}$ & $\begin{array}{r}21(77.8) \\
226(82.8) \\
\end{array}$ & $\begin{array}{c}6(22.2) \\
47(17.2) \\
\end{array}$ & 0.33 & $\begin{array}{l}19(70.4) \\
177(64.8 \\
\end{array}$ & $\begin{array}{c}8(29.6) \\
96(35.2) \\
\end{array}$ & .36 & $\begin{array}{r}18(66.7) \\
215(78.8) \\
\end{array}$ & $\begin{array}{r}9(33.3) \\
58(21.2) \\
\end{array}$ & .11 \\
\hline
\end{tabular}

- ${ }^{*} p \leq 0.05$

- \# Improper compliance include fair and poor compliance 
Table (4): Effect of disease characteristics on appointment, diet and drugs compliance

\begin{tabular}{|c|c|c|c|c|c|c|c|c|c|}
\hline \multirow[t]{2}{*}{ Variables } & \multicolumn{3}{|c|}{ Appointment } & \multicolumn{3}{|c|}{ Diet } & \multicolumn{3}{|c|}{ Drugs } \\
\hline & $\begin{array}{l}\text { proper } \\
\text { No }(\%)\end{array}$ & $\begin{array}{c}\text { improper } \\
\text { No (\%) }\end{array}$ & $\mathbf{P}$ & $\begin{array}{l}\text { proper } \\
\text { No }(\%)\end{array}$ & $\begin{array}{c}\text { improper } \\
\text { No (\%) }\end{array}$ & $\mathbf{P}$ & $\begin{array}{l}\text { proper } \\
\text { No (\%) }\end{array}$ & $\begin{array}{c}\text { improper } \\
\text { No (\%) }\end{array}$ & $\mathbf{P}$ \\
\hline $\begin{array}{l}\text { Type of } \\
\text { Diabetes } \\
\text { Type } 1 \\
\text { Type } 2\end{array}$ & $\begin{array}{c}20(90.9) \\
227(81.7)\end{array}$ & $\begin{array}{c}2(9.1) \\
51(18.3)\end{array}$ & 0.21 & $\begin{array}{c}7(31.8) \\
189(68.0\end{array}$ & $\begin{array}{l}15(68.2) \\
89(32.0)\end{array}$ & .00 & $\begin{array}{c}18(81.8) \\
215(77.3)\end{array}$ & $\begin{array}{c}4(18.2) \\
63(22.7)\end{array}$ & .43 \\
\hline $\begin{array}{l}\text { Duration } \\
\text { of } \\
\text { diabetes } \\
\text { Mean } \\
\pm S D \\
\end{array}$ & $\begin{array}{c}7.1 \\
\pm 5.2\end{array}$ & $\begin{array}{r}8.7 \\
\pm 6.2\end{array}$ & 0.3 & $\begin{array}{r}7.6 \\
\pm 4.9\end{array}$ & $\begin{array}{r}8.9 \\
\pm 6.1\end{array}$ & .04 & $\begin{array}{c}8.2 \\
\pm 5.6\end{array}$ & $\begin{array}{r}7.5 \\
\pm 4.5\end{array}$ & .32 \\
\hline $\begin{array}{l}\text { Complicati } \\
\text { on } \\
\text { No } \\
\text { Yes } \\
\end{array}$ & $\begin{array}{c}180(87.4) \\
67(71.3)\end{array}$ & $\begin{array}{l}26(12.6) \\
27(28.7)\end{array}$ & ${ }^{*}{ }^{*}$ & $\begin{array}{l}126(61.2 \\
70(74.5)\end{array}$ & $\begin{array}{l}80(38.8) \\
24(25.5)\end{array}$ & .01 & $\begin{array}{c}153(74.3) \\
80(85.1)\end{array}$ & $\begin{array}{l}53(25.7) \\
14(14.9)\end{array}$ & .02 \\
\hline $\begin{array}{l}\text { Family } \\
\text { history } \\
\text { Positive } \\
\text { Negative }\end{array}$ & $\begin{array}{l}129(78.2) \\
118(87.4)\end{array}$ & $\begin{array}{l}36(21.8) \\
17(12.6)\end{array}$ & $\begin{array}{c}{ }^{*} \\
0.02\end{array}$ & $\begin{array}{l}94(57.0) \\
102(57.6\end{array}$ & $\begin{array}{l}71(43.0) \\
33(42.4)\end{array}$ & $\begin{array}{c}* \\
.00\end{array}$ & $\begin{array}{l}131(79.4) \\
102(75.6)\end{array}$ & $\begin{array}{c}34(20.6) 33 \\
(24.4)\end{array}$ & .25 \\
\hline
\end{tabular}

\section{- ${ }^{*} p \leq 0.05$}

- † Improper compliance includes fair and poor compliance

Table (5): Effect of care characteristics on appointment, diet and drugs compliance

\begin{tabular}{|c|c|c|c|c|c|c|c|c|c|}
\hline \multirow[t]{2}{*}{ Variables } & \multicolumn{3}{|c|}{ Appointment } & \multicolumn{3}{|c|}{ Diet } & \multicolumn{3}{|c|}{ Drugs } \\
\hline & $\begin{array}{l}\text { proper } \\
\text { No }(\%)\end{array}$ & $\begin{array}{c}\text { improper } \\
\text { No (\%) }\end{array}$ & $\mathbf{P}$ & $\begin{array}{l}\text { proper } \\
\text { No }(\%)\end{array}$ & $\begin{array}{c}\text { improper } \\
\text { No (\%) }\end{array}$ & $\mathbf{P}$ & $\begin{array}{l}\text { proper } \\
\text { No }(\%)\end{array}$ & $\begin{array}{c}\text { improper } \\
\text { No (\%) }\end{array}$ & $\mathbf{P}$ \\
\hline $\begin{array}{l}\text { Type of } \\
\text { treatment } \\
\text { Oral } \\
\text { injection } \\
\text { Both }\end{array}$ & $\begin{array}{c}108(77.1) \\
64(88.9) \\
75(85.2)\end{array}$ & $\begin{array}{c}32(22.9) \\
8(11.1) \\
13(14.8)\end{array}$ & 0.07 & $\begin{array}{l}90(64.3) \\
41(56.9) \\
65(73.9)\end{array}$ & $\begin{array}{l}50(35.7) \\
31(43.1) \\
23(26.1)\end{array}$ & .07 & $\begin{array}{c}108(77.1) \\
50(69.4) \\
75(85.2)\end{array}$ & $\begin{array}{l}32(22.9) \\
22(30.6) \\
13(14.8)\end{array}$ & .06 \\
\hline $\begin{array}{l}\text { Frequency/d } \\
\text { ay } \\
\text { Once } \\
\text { Twice } \\
\text { Three or } \\
\text { more } \\
\end{array}$ & $\begin{array}{c}4(44.4) \\
35(71.4) \\
208(86.0)\end{array}$ & $\begin{array}{c}5(55.6) \\
14(28.6) \\
34(14.0)\end{array}$ & .00 & $\begin{array}{l}9(100.0) \\
34(69.4) \\
153(63.2\end{array}$ & $\begin{array}{c}0(0.0) \\
15(30.6) \\
89(36.8)\end{array}$ & .06 & $\begin{array}{c}9(100.0) \\
39(79.6) \\
185(76.4)\end{array}$ & $\begin{array}{c}0(0.0) \\
10(20.4) \\
57(23.6)\end{array}$ & .23 \\
\hline $\begin{array}{l}\text { No of total } \\
\text { drugs } \\
\text { One or two } \\
\text { Three or } \\
\text { more }\end{array}$ & $\begin{array}{l}141(91.0) \\
106(73.1)\end{array}$ & $\begin{array}{c}14(9.0) \\
39(26.9)\end{array}$ & .00 & $\begin{array}{l}102(70.3 \\
94(60.6)\end{array}$ & $\begin{array}{l}43(29.7) \\
61(39.4)\end{array}$ & .05 & $\begin{array}{l}119(82.1) \\
114(73.5)\end{array}$ & $\begin{array}{l}26(17.9) \\
41(26.5)\end{array}$ & $\stackrel{*}{*}$ \\
\hline $\begin{array}{l}\text { Care score } \\
{[\text { mean } \pm \text { SD] }}\end{array}$ & $6.4 \pm 3.4$ & $5.7 \pm 2.5$ & 0.23 & $6.3 \pm 3.2$ & $6.4 \pm 3.4$ & .86 & $6.5 \pm 3.3$ & $5.7 \pm 3.1$ & .16 \\
\hline $\begin{array}{l}\text { Diabetes } \\
\text { control } \\
\text { (FBS) } \\
\text { Good } \\
\text { Bad }\end{array}$ & $\begin{array}{c}45(81.8) \\
202(82.4)\end{array}$ & $\begin{array}{l}10(18.2) \\
43(17.6\end{array}$ & .91 & $\begin{array}{l}48(87.3) \\
148(60.4\end{array}$ & $\begin{array}{c}7(12.7) \\
97(39.6)\end{array}$ & ${ }^{*}$ & $\begin{array}{c}45(81.8) \\
188(76.7)\end{array}$ & $\begin{array}{l}10(18.2) \\
57(23.3)\end{array}$ & .41 \\
\hline
\end{tabular}

- ${ }^{*} p \leq 0.05$

- $\quad$ † Improper compliance includes fair and poor compliance 
Table (6) significant predictors of improper appointment, diet, drugs and total compliance

\begin{tabular}{|c|c|c|c|c|c|}
\hline \multirow{2}{*}{ Variables } & \multirow{2}{*}{$\begin{array}{c}\text { B } \\
\text { coefficient }\end{array}$} & \multirow{2}{*}{ P-Value } & \multirow{2}{*}{ Odd' ratio } & \multicolumn{2}{|c|}{$95.0 \% \mathrm{Cl}$. for $\operatorname{EXP}(\mathrm{B})$} \\
\hline & & & & Lower & Upper \\
\hline \multicolumn{6}{|c|}{ Significant predictors of improper appointment compliance } \\
\hline $\begin{array}{l}\text { Taking } \geq 3 \\
\text { drugs }\end{array}$ & 1.04 & 0.01 & 2.85 & 1.19 & 6.80 \\
\hline $\begin{array}{l}\text { Frequency of } \\
\text { Drugs } \\
\geq 3 \text { /day }\end{array}$ & .86 & .04 & 2.37 & 1.03 & 5.44 \\
\hline \multicolumn{6}{|c|}{ Significant predictors of improper diet compliance } \\
\hline Age & -.06 & .01 & .93 & .89 & .98 \\
\hline $\begin{array}{l}\text { Disease } \\
\text { duration }\end{array}$ & .09 & .00 & 1.10 & 1.03 & 1.17 \\
\hline $\begin{array}{ll}+\quad \text { ve } & \text { Family } \\
\text { history } & \end{array}$ & 1.46 & .00 & 4.34 & 2.10 & 8.97 \\
\hline $\begin{array}{l}\text { Bad Drug } \\
\text { compliance }\end{array}$ & 3.18 & .00 & 24.26 & 10.57 & 55.67 \\
\hline \multicolumn{6}{|c|}{ Significant predictors of improper drugs compliance } \\
\hline $\begin{array}{l}\text { Bad diet } \\
\text { compliance }\end{array}$ & 2.40 & .00 & 11.12 & 5.61 & 22.03 \\
\hline
\end{tabular}

Table (7): Reasons of improper compliance as stated by the patients

\begin{tabular}{|c|c|c|}
\hline Reasons & No & Percent \\
\hline \multicolumn{3}{|c|}{ Improper appointment (no= 53) } \\
\hline Felt good health & 17 & 32.1 \\
\hline Unsuitable clinic time & 15 & 28.3 \\
\hline Patient was tired & 11 & 20.8 \\
\hline Far distance of the clinic & 10 & 18.8 \\
\hline \multicolumn{3}{|c|}{ Improper diet compliance(no=104) } \\
\hline Financial constraints & 43 & 41.3 \\
\hline Psychological constraints & 30 & 28.9 \\
\hline According to available diet at home & 25 & 24.0 \\
\hline Outdoor life & 6 & 5.8 \\
\hline \multicolumn{3}{|c|}{ Improper drug compliance (no=67) } \\
\hline Expensive drugs & 47 & 70.1 \\
\hline Forgetfulness & 7 & 10.5 \\
\hline Not feeling benefits of drugs & 6 & 8.9 \\
\hline Occurrence of side effects & 4 & 5.9 \\
\hline Use of multiple drugs & 3 & 4.6 \\
\hline
\end{tabular}




\section{REFERENCES}

1. Wild S, Roglic G, Green A, Sicree R, King $H$. Global Prevalence of Diabetes: Estimates for the year 2000 and projections for 2030. Diabetes Care. 2004;27:1047-1053.

2. Yach D, Stuckler D, Brownell KD. Epidemiologic and economic consequences of the global epidemics of obesity and diabetes. Nat Med. 2006;12:62-66.

3. Delamater A.M. Improving Patient Adherence Clinical Diabetes.2006;24:71-77.

4. World Health Organization. Adherence to Long term Therapies: Evidence for Action. Geneva, 2003. 212 pp. ISBN 92-4-154599-2. Report 2003

5. Meichenbaum D, Turk DC: Facilitating Treatment Adherence: A Practitioner's Guide-book. New York, Plenum Press, 1987

6. Boehm S, Schlenk EA, Funnell MM, Powers H, Ronis DL. Predictors of adherence to nutrition recommendations in people with noninsulin-dependent diabetes mellitus. Diabetes Educ. 1997;23:157 -165

7. Schaepelnynck-BelicarP, DufaitrePatouraux L, Lassmann-Vague V: What could be the reasons for giving up the implanted insulin pump? Diabetes Metab. 2005 ;31: 87-89

8. Delamater AM, Jacobson AM, Anderson BJ, Cox D, Fisher L, Lustman P, Rubin R, Wysocki T. Psychosocial therapies in diabetes: report of the Psychosocial Therapies Working Group. Diabetes Care. 2001;24 : 1286-1292

9. World Medical Association Declaration of Helsinki (2000): Ethical Principles for Medical Research Involving Human Subjects. Revised by the 52nd WMA General Assembly, Edinburgh, Scotland, October 2000.URL: http://www.wma.net/e/policy/b3.htm retrieved in June/ 2000

10. Khattab MS, Abolfotouh MA, Khan MY, Humaidi MA, andAlKaldi YM. Compliance and control of diabetes in a family practice setting, Saudi Arabia. Eastern Mediterranean Health Journal 1999;5 (4): 755-765.

11. Diabetes Quality Improvement Project: Available from URL: http://www.hcfa.gov/quality/3L.htm. retrieved 6/2007

12. Gulliford MC, Mahabir D, Ukoumunne OC. Evaluating variations in medical practice between government primary health care centres. J Clin Epidemiol. 2001; 54:511-517.

13. American Diabetes Association, Standard of medical care 2007 Diabetes Care. 2007(30):S4-S41

14. Haynes RB, Taylor DW, Sackett DL. Compliance in health care. Baltimore, Md., Johns Hopkins University Press, 1979.

15. Kravitz RL, Hays RD, Sherbourne CD, DiMatteo MR, Rogers WH, Ordway L, Green-field S. Recall of recommendations and adherence to advice among patients with chronic medical conditions. Arch Intern Med. 1993;153: 1869-1878

16. Peyrot M, Rubin RR, Lauritzen T, Snoek FJ, Matthews DR, Skovlund SE. Psychosocial problems and barriers to improved diabetes management: results of the CrossNational Diabetes Attitudes, Wishes and Needs (DAWN) Study. Diabet Med, 2005; 22:1379 -1385.

17. Paes AHP, Bakker A, Soe-Agnie CJ: Impact of dosage frequency on patient compliance. Diabetes Care. 1997; 20:1512 -1517.

18. Kyngas $\mathrm{H}$ : A theoretical model of compliance in young diabetics. Journal of Clinical Nursing, 1999; 8: 73-80. 
19. Dietrich UC. Factors influencing the attitudes held by women with type II diabetes: a qualitative study. Patient Educ Couns. 1996 Oct;29 (10):13-23

20. Clarke D, and Goosen T: Depression and compliance with treatment in a sample of Northland diabetes patients journal of the New Zealand medical association.2005; 16(118):1222-1230.

21. Donnan PT, MacDonald TM, Morris $\mathrm{AD}$, for the DARTS/MEMO Collaboration. Adherence to prescribed oral hypoglycemic medication in a population of patients with type 2 diabetes: a retrospective cohort study. Diabet Med. 2002;19:279-284.

22. American Diabetes Association: Clinical Practice Recommendations 2001. Diabetes Care 24 (Suppl.1):S1S133, 2001.
23. Clark Jr CM, Lee DA. Prevention and treatment of complications of diabetes. New England journal of medicine, 1995; 332:1210-7

24. American Diabetes Association: Hyperglycemic crisis in diabetes (Position Statement). Diabetes Care.2004;27:S94 -S102.

25. Schafheutle El, Hassell K, Noyce PR, Weiss MC. Access to medicines: cost as an influence on the views and behaviour of patients. Health Soc Care Community. 2002;10:187-195.

26. Ciechanowski PS, Katon WJ, Russo JE, Hirsch IB. Depression and diabetes: impact of depressive symptoms on adherence, function, and costs. Arch Intern Med. 2000;160:3278-3285 